San Antonio Review • San Antonio Review (Volume V | Summer 2021)

\title{
Timeline of Irresponsibility
}

William O. Pate II

${ }^{1}$ San Antonio Review

Published on: Mar 31, 2021

DOI: $10.21428 / 9 b 43 c d 98 . a e 7 e d 450$

License: Creative Commons Attribution 4.0 International License (CC-BY 4.0). 


\section{January 2020}

January 21, 2020: First novel coronavirus case detected in the United States of America. 1

\section{March 2020}

March 4, 2020: First coronavirus case in Texas. $\underline{2}$

March 11, 2020: World Health Organization declares $\underline{\text { COVID-19 pandemic. }} . \underline{3}$

March 13, 2020: Texas Gov. Greg Abbott declares a state of disaster (enabling federal funds to flow to the state) and halts elective surgeries (including abortions). $\underline{4}$

March 16, 2020: First COVID-19 death in Texas. $\underline{5}$

March 19, 2020: Texas Gov. Greg Abbott issues first coronavirus-related executive order shutting down government and businesses and banning gatherings. $\underline{6}$

March 23, 2020: Texas Lt. Gov. Dan Patrick offers to sacrifice Texas seniors to coronavirus in order to reopen the Texas economy. $\underline{?}$

\section{April 2020}

April 14, 2020: Texas Attorney General Ken Paxton, under indictment for nearly six years, issues a letter to Texas House of Representatives Elections Committee Chair Rep. Stephanie Klick stating his "unofficial opinion" that "fear of contracting COVID19 unaccompanied by a qualifying sickness or physical condition does not constitute a disability under the Election Code for purposes of receiving a ballot by mail."푸 President Donald Trump halts funding for the World Health Organization. $\underline{9}$

April 15, 2020: U.S. District Court Judge Tim Sulak rules in favor of allowing all Texans to vote by mail during coronavirus pandemic. $\underline{10}$

April 17, 2020: Texas Gov. Greg Abbott issues executive order announcing the establishment of the 45-member Governor's Strike Force to Open Texas and the beginning of the first phased reopening of Texas businesses. $\underline{11}$

April 23, 2020: U.S. President Donald J. Trump suggests people infected with coronavirus get an "injection" of disinfectant as a deterrent to the virus during his daily briefing. $\underline{\underline{12}}$ 
April 24, 2020: Austin police officers shoot and kill unarmed Mike Ramos. $\underline{13}$

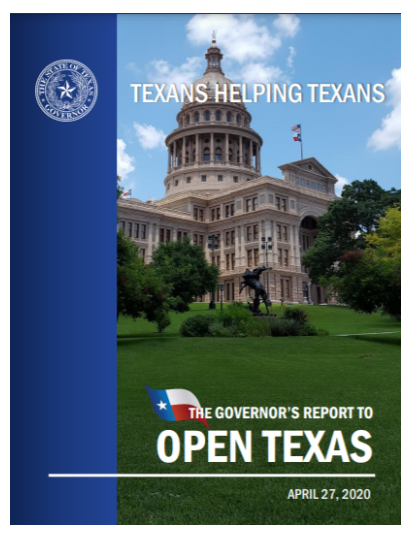

Cover image of The Governor's Report to Open Texas
April 27, 2020: Governor's Strike Force to Open Texas releases The Governor's Report to Open Texas: Texans Helping Texans with health and safety guidelines for individuals, employers, employees, the business sector and low-COVID counties along with celebratory biographies of the business leaders on the strike force and self-congratulatory reprisals of Gov. Abbott's (non-)response so far. $\underline{14}$

\section{May 2020}

May 1, 2020: Texas begins Phase I of reopening. $\underline{15}$ Texas Attorney General Ken Paxton issues letter to county judges and election officers threatening prosecution for encouraging

Texans to vote by mail. $\underline{16}$

To the extent third parties advise voters to apply for a ballot by mail for reasons not authorized by the Election Code, including fear of contracting COVID-19 without an accompanying qualifying disability, such activity could subject those third parties to criminal sanctions imposed by Election Code section 84.0041 . TEX. ELEC. CODE $\S 84.0041$ (providing that a person commits an offense if the person "intentionally causes false information to be provided on an application for ballot by mail"); see also id. $\$ 276.013$ (a person commits election fraud if the person knowingly or intentionally causes a ballot to be obtained under false pretenses, or a misleading statement to be provided on an application for ballot by mail). However, whether specific activity constitutes an offense under these provisions will depend upon the facts and circumstances of each individual case.

Excerpt from Texas Attorney General Ken Paxton's letter to county election officials.

May 5, 2020: Audio leaked of Texas Gov. Greg Abbott acknowledging reopening will increase transmission of COVID-19. $\frac{17}{}$

Visit the web version of this article to view interactive content.

Leaked Audio (Full): Gov. Abbott Knows Reopening Will Cause an Increase in Infection Rate for Texans

May 18, 2020: Texas begins Phase II of reopening. 
"Our goal is to find ways to coexist with COVID-19 as safely as possible."

- Texas Gov. Greg Abbott $\underline{18}$

May 19, 2020: U.S. District Judge Fred Biery rules that all state voters regardless of age qualify for a mail-in ballot during the coronavirus pandemic. $\underline{19}$

May 25, 2020: George Floyd murdered by police officer Derek Chauvin in Minneapolis. $\underline{20}$ No arrests are made.

May 27, 2020: Texas Supreme Court opines in official ruling that most Texans won't get coronavirus. $\frac{21}{1}$

JUSTICE BOYD and JUSTICE BLAND would hold that a lack of immunity to COVID-19 is a "physical condition" under $\S 82.002$ (a), though a voter would not be entitled to vote by mail without a "likelihood" that voting in person would injure the voter's health. We all agree that "likelihood" means a probability. But for the population overall, contracting COVID-19 in general is highly improbable. This is not to say that the risk is not greater for certain persons or in certain situations, as we have noted. Indeed, that improbability has justified the efforts throughout the state to reopen business and activities in a gradual return to normalcy. In addition, as the State highlights, authorities planning elections are working in earnest to ensure adherence to social distancing, limits on the

\section{Excerpt from Texas Supreme Court opinion.}

May 29, 2020: Derek Chauvin finally arrested after worldwide protests. $\underline{22}$ President Donald Trump terminates U.S. relationship with World Health Organization. $\underline{23}$

May 29-31, 2020: Anti-racist protests break out in response to George Floyd's murder and the failure of public officials to arrest the police officers involved:

Texans protested in Austin, Houston, Dallas, San Antonio and Fort Worth throughout the weekend, spurred by the death of George Floyd, a black man who was killed in Minneapolis police custody Monday. Floyd had been a longtime resident of Houston's Third Ward. $\underline{24}$

May 31, 2020: Gov. Greg Abbott declares the entire state of Texas a disaster in response to protests in some cities, allowing him to designate federal law enforcement 
officers to perform the duties of peace officers in Texas. $\underline{25}$

\section{June 2020}

June 3, 2020: Texas begins Phase III of reopening. $\underline{26}$

June 25, 2020: Elective surgeries (including abortions) suspended in Texas metros due to coronavirus overloading hospitals.

June 26, 2020: Texas Gov. Greg Abbott reverses reopening state after a tremendous increase in coronavirus cases and deaths.

\section{July 2020}

July 2, 2020: Texas Gov. Greg Abbott finally issues statewide mask order for counties with over 20 cases of COVID-19. 27

\section{August 2020}

August 17, 2020: $10,000^{\text {th }}$ Texan dies of COVID-19. $\underline{28}$

\section{September 2020}

Texas Gov. Greg Abbott quietly disbands his Strike Force to Open Texas. $\underline{29}$

September 17, 2020: Texas Gov. Greg Abbott begins reopening Texas businesses again. $\underline{30}$

\section{October 2020}

October 14, 2020: Texas bars allowed to reopen. $\underline{31}$

\section{November 2020}

November 3, 2020: President Trump fails to win reelection as president but refuses to concede. Texas voter turnout best in nearly three decades. $\underline{32}$ Thus explaining Republican attempts to pass voter-suppression legislation in 2021.

November 16, 2020: Texas becomes first state to surpass 1 million coronavirus cases. $\underline{33}$

\section{January 2021}

January 6, 2021: Insurrection at the U.S. Capitol after a pro-Trump rally, which Texas Attorney General Ken Paxton attended. $\underline{34}$ 
Graphic Videos Detail Violence at US Capitol on January 6 - WATCH LIVE / Voice of America - English. https://www.voanews.com/usa/us-politics/graphic-videos-detailviolence-us-capitol-january-6-watch-live. Accessed 15 June 2021.

January 28, 2021: President Joe Biden revives U.S. funding for World Health Organization. $\underline{35}$

\section{February 2021}

February 10, 2021: Texas Gov. Greg Abbott's office informed of looming natural gas shortages by Public Utility Commission of Texas Chair DeAnne Walker. $\underline{36}$

February 11, 2021: Texas Lt. Gov. Dan Patrick announces plan to penalize environmentally sensitive investors..$\underline{37}$

February 13-17, 2021: Winter Storm Uri strikes Texas causing cascading failures of energy and public health infrastructure (gas, electric, water). Death toll: at least 210 people. (State's initial count was 111.) $\underline{38}$ A tally by the Houston Chronicle finds almost double the number of deaths. $\underline{39}$ A BuzzFeed News data analysis estimates 700 deaths from the storm. $\underline{40}$

February 16, 2021: The Texas Public Utility Commission orders that wholesale electricity prices in the state should be set at $\$ 9,000$ per megawatt-hour. $\underline{41}$

That's exactly what happened: energy prices skyrocketed. Now, as the dust is settling and the Texas Legislature has adjourned after passing several bills that aimed to fix the state's fragile electric grid, three truths have become clear: the 
state's policymakers have not done enough to ensure the resilience and reliability of the grid, the February 16 PUC order kept electricity prices far too high for far too long, and Texas ratepayers will ultimately be saddled with about $\$ 37.7$ billion in excess energy costs. $\underline{42}$

Chart 1

ERCOT Electricity Generation by Source, Demand and Outages During Texas Deep Freeze

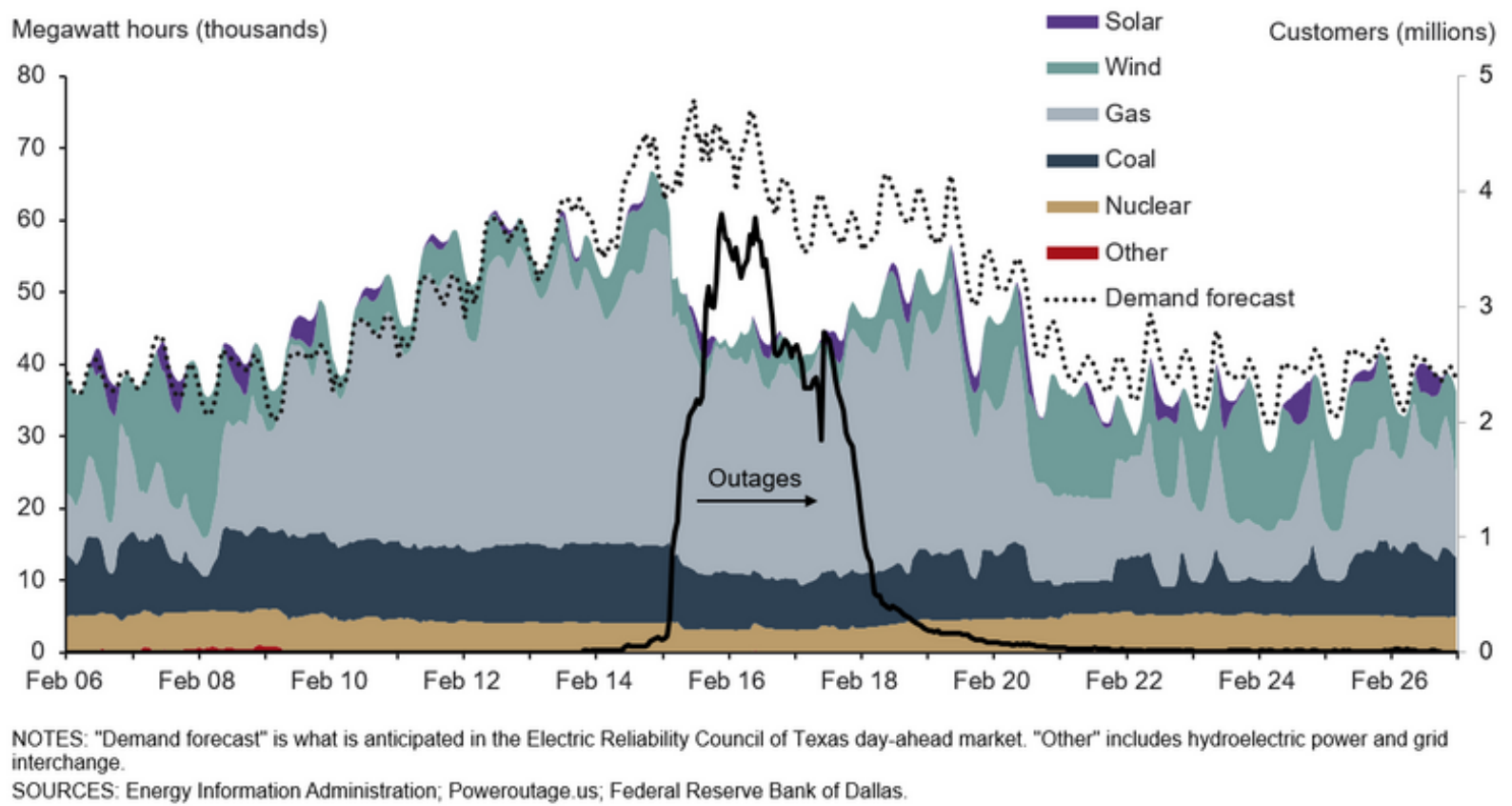

Federal Reserve Bank of Dallas

Cost of Texas' 2021 Deep Freeze Justifies Weatherization.

https://www.dallasfed.org:443/research/economics/2021/0415. Accessed 16 Apr. 2021.

February 17, 2021: Gov. Greg Abbott falsely blames renewable energy for power outages in Texas. $\underline{43}$ U.S. Senator Ted Cruz, Republican of Texas, flies to Cancun, Mexico to escape freezing weather, leaving his constituents (and pet dog) behind. $\underline{4}$ Texas Attorney General Ken Paxton in Salt Lake City, Utah. $\underline{45}$ Republican Texas state Rep. Gary Gates abandons constituents via private jet to Orlando, Florida. $\underline{46}$

"Texans would be without electricity for longer than three days to keep the federal government out of their business."

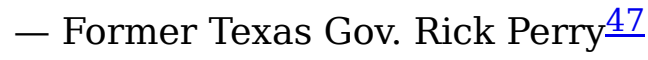

February 17-18, 2021: ERCOT's visitor logs show Ryland Ramos, Gov. Greg Abbott's top energy policy adviser, and Abbott-appointed Public Utility Commission chair DeAnn Walker - along with top regulatory officials from Centerpoint Energy, Oncor, AEP and 
Texas-New Mexico Power Company - signed in at the agency's operations center in Taylor, where ERCOT's high-tech control room handling the flow of power to most Texans, is located at about 10 p.m. on Wednesday, February 17, and stayed there until 8:49 a.m. the next day.

The timeline in the visitor logs means the Abbott aide was on the scene when ERCOT decided - just before midnight Wednesday - to quit ordering rolling power outages and then, in the wee hours of Thursday, to leave the maximum prices for electricity in place. $\underline{48}$

February 18, 2021: At least 3.4 million Texans without power. $\underline{49}$

February 19, 2021: 13.5 million Texans experience water disruption. $\underline{50}$ Texas Attorney General Ken Paxton still in Salt Lake City, Utah. $\underline{51}$

Visit the web version of this article to view interactive content.

Letter to Gov. Greg_Abbott from Bexar County_Judge Nelson Wolff, 19 February 2021.

\section{March 2021}

March 2, 2021: Texas Gov. Greg Abbott lifts statewide mask mandate and "reopens Texas 100 percent." $\underline{52}$

March 9, 2021: Texas Public Utility Commission Chairman Arthur D'Andrea, who was appointed by Gov. Greg Abbott, tells investors on a Bank of America Securities-hosted call to expect little improvement to the Texas energy grid and that he would attempt to protect their windfall profits from Winter Storm Uri. $\underline{53}$ The call was closed to the public and news media and later leaked to Texas Monthly..$\underline{54}$

March 10, 2021: Texas Attorney General Ken Paxton threatens to sue the city of Austin and Travis County if they don't lift requirements for mask-wearing inside local businesses. $\underline{55}$ 
We have already taken you to court under similar circumstances. You lost. If you continue to flout the law in this manner, we'll take you to court again and you will lose again.

To that end, you and your local health authorities have until 6:00 p.m. today to rescind any local mask mandates or business-operating restrictions, retract any related public statements, and come into full compliance with GA-34. Otherwise, on behalf of the State of Texas, I will sue you.

For Liberty and Justice in Texas,

KEN PAXTON

Attorney General of Texas

cc: Dr. Mark Escott, Austin Public Health

Excerpt of letter from Texas Attorney General Ken Paxton to Austin and Travis county leaders.

March 11, 2021: Texas Attorney General Ken Paxton sues to block Austin and Travis County pandemic orders requiring employees and customers to wear a face-covering in local businesses. $\underline{56}$

March 12, 2021: State District Judge Lora Livingston declines Texas Attorney General Ken Paxton's request to block Austin mask mandates until a full hearing. $\underline{57}$

March 25, 2021: Texas Attorney General Ken Paxton refuses to release emails and text messages he sent during the rally in Washington, D.C. that resulted in the January $6^{\text {th }}$ Capitol insurrection. $\underline{58}$ U.S. Sen. Ted Cruz, R-Texas, refuses to wear mask during press conference. $\underline{59}$

Paxton is a stain on Texas integrity, what remains of it, and should have faced trial on his pending felony charges years ago or at least been shunned by Gov. Greg Abbott and other party leaders when his own top staff accused him last year of abuse of office, bribery, improper influence and other possible criminal acts.

If he had an ounce of shame, he would follow President Nixon's example from 1974, and the perpetual advice from this editorial board, and resign.

Instead, Paxton last week gave Texas another reminder of how ill-suited he is to play the dual role of suspected criminal and Texas attorney general. Reporters from Houston, Dallas and throughout Texas have been asking his office to share - as the law requires - his texts, emails and other messages from on and around Jan. 6, the day of infamy in the U.S. Capitol. Paxton had flown to Washington to speak at the rallies leading up to the armed insurrection - although at whose request and on whose dime, he won't say.

Excerpt from a Houston Chronicle editorial from March 30, 2021 
March 26, 2021: State District Judge Lora Livingston rules against Texas Attorney General Ken Paxton and in favor of allowing Austin's mask mandate to continue. $\underline{60}$

March 29, 2021: President Joe Biden urges states to reinstate and/or continue mask mandates. $\underline{61}$

\section{April 2021}

April 1, 2021: Republicans in the Texas Senate pass voter-suppression legislation. $\underline{62}$ Senate Bill 7 would:

- Limit early voting to the hours of 6 AM to 9 PM (thus making it more difficult for shift workers and others on non-9-to-5 schedules to vote);

- Ban drive-thru voting;

- Prohibit local elections officials from encouraging qualified (read: disabled and elderly) voters to apply for mail-in ballots (thus ensuring no one ever learns of the opportunity ever again);

- Strengthen the authority of partisan poll watchers to challenge voters, including allowing them to video voters receiving assistance in filling out their ballots. $\underline{63}$

\section{May 2021}

May 17, 2021: Texas Gov. Greg Abbott prematurely ends the state's participation in the federally funded pandemic-related unemployment programs effective June $26^{\text {th }} . \underline{64}$ Texas will stop participating in ARPA programs, including Federal Pandemic Unemployment Compensation (FPUC), Pandemic Emergency Unemployment Compensation (PEUC), Pandemic Unemployment Assistance (PUA) and the Mixed Earners Unemployment Compensation Program (MEUC). This includes the \$300 weekly unemployment supplement from the FPUC. $\underline{65}$ U.S. Federal Reserve issues results of latest Survey of Household Economics and Decisionmaking, Economic WellBeing of U.S. Households in 2020, revealing a quarter of American adults worse off at the end of 2020 than at the same time in 2019. $\underline{66}$ Over a third of Americans reported not being able to afford to cover a $\$ 400$ emergency with on-hand cash or its equivalent. $\frac{67}{}$ 
Adults doing worse off than 12 months ago

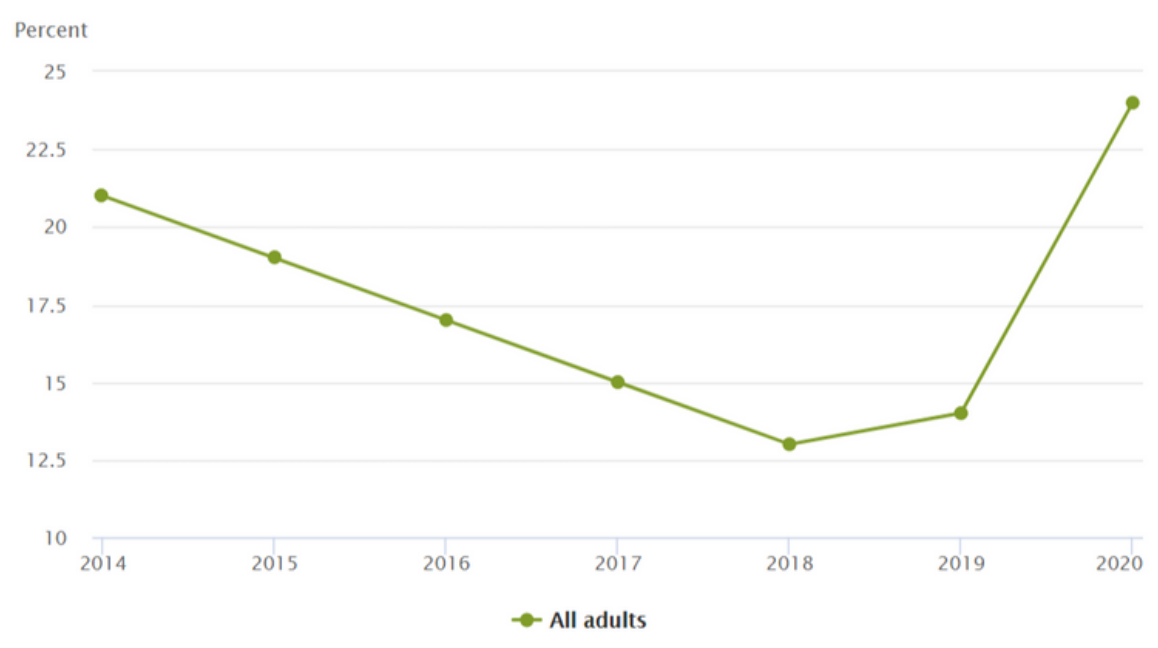

Image from Survey of Household Economics and

Decisionmaking,2013-2020. Accessed 19 May 2021.

Adults who would cover a $\$ 400$ emergency expense using cash or its equivalent Percent

Make Full Screen [

\begin{tabular}{|c|c|}
\hline Survey Year & Would handle $\$ 400$ expense with cash or equivalent \\
\hline 2013 & 50 \\
\hline 2014 & 53 \\
\hline 2015 & 54 \\
\hline 2016 & 56 \\
\hline 2017 & 59 \\
\hline 2018 & 61 \\
\hline 2019 & 63 \\
\hline 2020 & 64 \\
\hline
\end{tabular}

Note: Among all adults.

Image from Survey of Household Economics and Decisionmaking, 2013-2020. Accessed 28 May 2021. 


\section{Texas Employers:}

Today. Governor Abbott announced that Texas would no longer participate in the federally funded unemployment programs effective June $26^{\text {th }}$. Texas will stop participating in ARPA programs, including Federal Pandemic Unemployment Compensation (FPUC), Pandemic Emergency Unemployment Compensation (PEUC). Pandemic Unemployment Assistance (PUA) and the Mixed Earners Unemployment Compensation Program (MEUC). TWC and our Workforce Solutions partners continue to offer services to assist individuals in finding employment and their training needs. We will be providing additional information to claimants as we transition away from these programs.

You can see Governor Abbott's announcement at the following link: https:llgovtexas, govinews/post/governor-abbott-announces-end-to-tederal-pandemic-relatedunemployment-benefits

Also, here is the link to the letter he sent to the Department of Labor: https://gov.texas.gov/uploads/files/press/O-WalshMartin202105171215.pdf

In addition, please join the Office of the Commissioner Representing Employers and the Office of the Governor-Economic Development \& Tourism Division on Thursday, May $20^{\text {th }}$ at 10:00am as we hear from a number of industry association experts discussing best practices, resources and strategies for recruiting, hiring and retaining potential

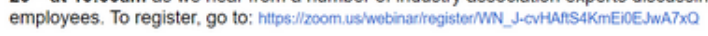

Industry Associations/Partners include the following: Workforce Solutions. Texas Economic Development Corporation, Texas Association of Business, National Federation of Independent Business-Texas, Texas Travel Alliance, Texas Chamber of Commerce Executives, Texas Truckers Association, Texas Association of Builders and the Texas Restaurant Association.

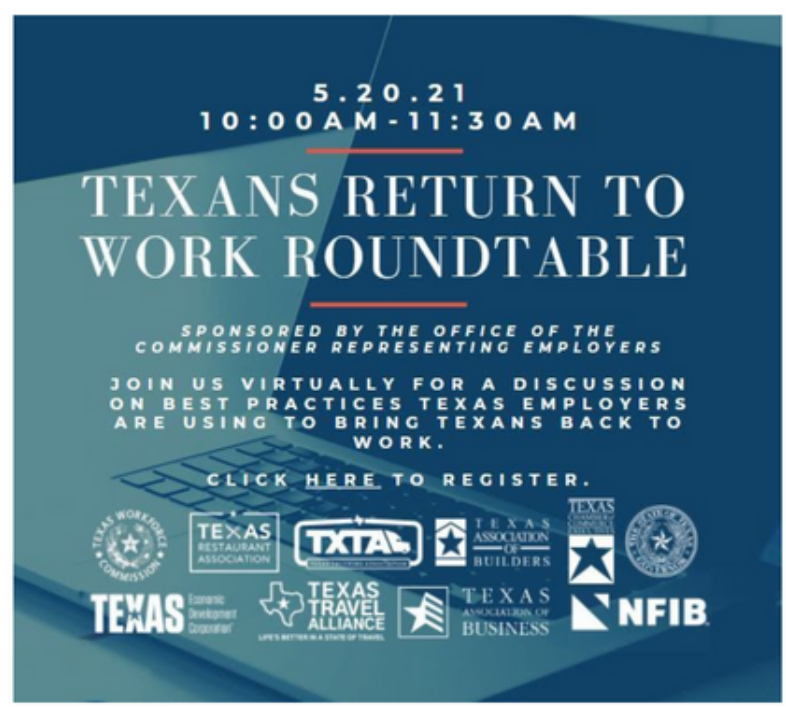

Sincerely,
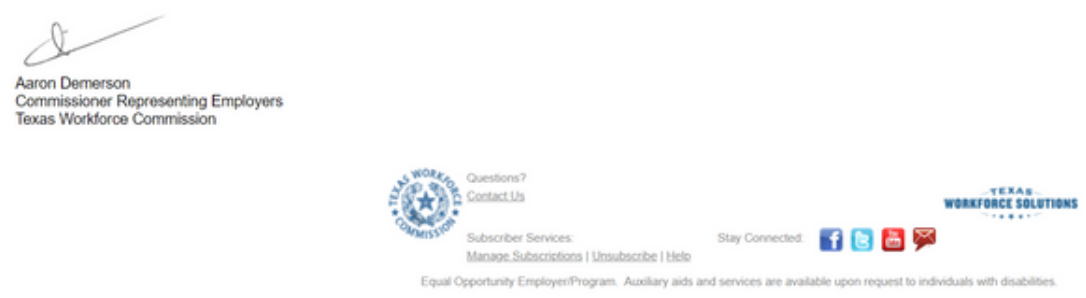

Screenshot of Email from Texas Workforce Commission announcing Gov. Abbott's termination of enhanced unemployment benefits for coronavirus-affected workers. / William O. Pate II, May 19, 2021

May 18, 2021: Texas Gov. Greg Abbott issues executive order barring state and local government entities (including counties, cities, school districts and public health 
authorities) and officials from requiring people to wear masks. Failure to comply can result in a $\$ 1,000$ fine, he notes in the executive order. $\underline{68}$ Mask ban becomes effective on May 22, 2021. School districts can require them until June 5.

May 27, 2021: Texas Legislature ends $87^{\text {th }}$ Legislative Session without meaningfully addressing health or energy crises facing the state.

Even as officials and statisticians continued to tally the dead from the February blackouts, legislators rushed forward with promises that they would make certain the grid never failed again. But the House and Senate could not agree on what measures to pursue. And both bodies were hamstrung by their deference to energy executives and investors, and especially natural gas producers. A slate of bills languished until the final Sunday of the session. The ones that passed would overhaul the state's Public Utility Commission and require weatherization of power plants, transmission lines, and the natural gas facilities that provide the fuel to generate power-but they do not specify how to pay for it. Nor do they address how to pay for the financial losses power companies faced in the stormlosses that Texas households and businesses will likely be footing for years to come. $\underline{69}$

May 28, 2021: U.S. Senate Republicans block the creation of a commission to investigate January $6^{\text {th }}$ insurrection at U.S. Capitol after Republican U.S. Senate Minority Leader Mitch McConnell asks "a personal favor" of fellow Republicans to vote against it. $\underline{70}$

May 31, 2021: Texas Gov. Greg Abbott threatens via Twitter to veto funding for legislative staff in revenge for Democrats breaking quorum to kill voter-suppression legislation under consideration by the Texas House of Representatives. 


\section{Greg Abbott}

@GregAbbott_TX

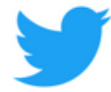

I will veto Article 10 of the budget passed by the legislature.

Article 10 funds the legislative branch.

No pay for those who abandon their responsibilities.

Stay tuned.

31 May $2021 \cdot 18: 13$

www.pikaso.me

Image 1

San Antonio Review

@SanAntoReview

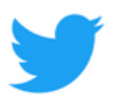

@GregAbbott_TX How long have your paychecks been stopped?

3 Jun $2021 \cdot 12: 32$

www.pikaso.me

Image 2

\section{June 2021}

Of nearly 10,000 bills and resolutions filed this session, about 3,800 were passed. The governor vetoed 21 pieces of legislation this session. In each of the last two 
regular sessions, he vetoed about 50 .

- Allie Morris, "From backing the blue to the 'Star-Spangled Banner': Bill that are becoming law in Texas," Dallas Morning News, 21 June 2021

June 1, 2021: U.S. Sen. John Cornyn, Republican of Texas, calls concerns about climate change "a cult" at the Tyler Area Chamber of Commerce Energy Summit. 11 Gov. Greg Abbott signs House Bill 1900, which financially penalizes cities that cut or reallocate their police budgets; Senate Bill 23, which forces counties with populations of 1 million or more to receive voter approval before decreasing their law enforcement budgets; and House Bill 2366, which increases penalties for interfering with or harming law enforcement. Senate Bill 68, which would have required peace officers to intervene and report when a fellow officer uses excessive force was left unsigned. $\underline{72}$ Significantly, Abbott's signature on HB 1900 law restores funds, personnel and authority for tasks earlier removed from Austin Police Department by the city council.

Under that law - which takes effect Sept. 1, after the City Council adopts the budget in August but before FY 22 begins Oct. 1 - APD's budget this year has to be at least $\$ 432$ million; otherwise, the state can siphon off Austin's sales tax revenue and prevent it from increasing property taxes or utility rates. The statute would also not only prevent Austin from annexing any territory until it made APD whole, but would require the city to hold disannexation elections in each area annexed in the last 30 years. $\underline{73}$

June 2, 2021: Texas Attorney General Ken Paxton tells Steve Bannon that former President Donald Trump would have lost in Texas in the 2020 election if his office had not successfully blocked counties from mailing out applications for mail-in ballots to all registered voters. $\underline{74}$

June 8, 2021: Texas Gov. Greg Abbott declares that legislation passed during the session "fixes all of the flaws" of the Texas energy grid.

"Bottom line is that everything that needed to be done was done to fix the power grid in Texas."

- Texas Gov. Greg Abbott모

June 14, 2021: Texas Gov. Greg Abbott signs Senate Bill 6, which shields companies from lawsuits for pandemic-related injuries or deaths and makes it more difficult to sue 
health care providers or businesses for exposures to illnesses arising from COVID-19 or future pandemics. $\underline{76}$

June 15, 2021: Texas Gov. Greg Abbott signs House Bill 1925, which is a statewide camping ban, making it a Class $\mathrm{C}$ misdemeanor to camp in unapproved public spaces. $\underline{77}$

June 17, 2021: Texas Gov. Greg Abbott signs Senate Bill 1111, prohibiting Texans from registering to vote using a commercial post office box (as many homeless do). $\underline{78}$

June 18, 2021: Texas Gov. Greg Abbott vetoes funding for the legislative branch in revenge for Texas House Democrats who broke quorum to prevent Senate Bill 7 from reaching the floor. $\underline{79}$

June 22, 2021: Texas Gov. Greg Abbott issues call for first special legislative session to begin on July 8,2021 , with legislative priorities to be added later. $\underline{80}$

\section{July 2021}

July 4, 2021: 50 percent of eligible Texans are fully vaccinated, according to The Dallas Morning News' data. $\underline{81}$

July 7, 2021: Texas Gov. Greg Abbott issues agenda for first called special session that focuses on restricting voting rights, blocking refugees from seeking asylum at the

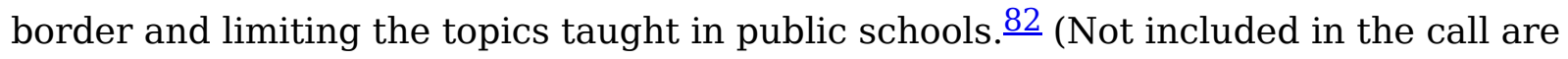
public health or energy infrastructure.)

July 23, 2021: After hospitalizations increase with the spread of the Delta variant of COVID-19, Austin reenters Stage 4 of its COVID-19 risk-based guidelines. $\underline{83}$

U.S. Centers for Disease Control and Prevention interpretive summary for the week states:

The United States is once again seeing a rise in COVID19 cases, hospitalizations, and deaths. As of July 22, 35\% of U.S. counties are experiencing high levels of community transmission. COVID-19 cases are on the rise in nearly

$\mathbf{9 0 \%}$ of U.S. jurisdictions, and we are seeing outbreaks in parts of the country that have low vaccination coverage. These worrisome trends are due, in part, to the rapid spread of the highly transmissible B.1.617.2 (Delta) variant. An increase in the number of cases will put more strain on healthcare resources and could lead to more hospitalizations and deaths. 

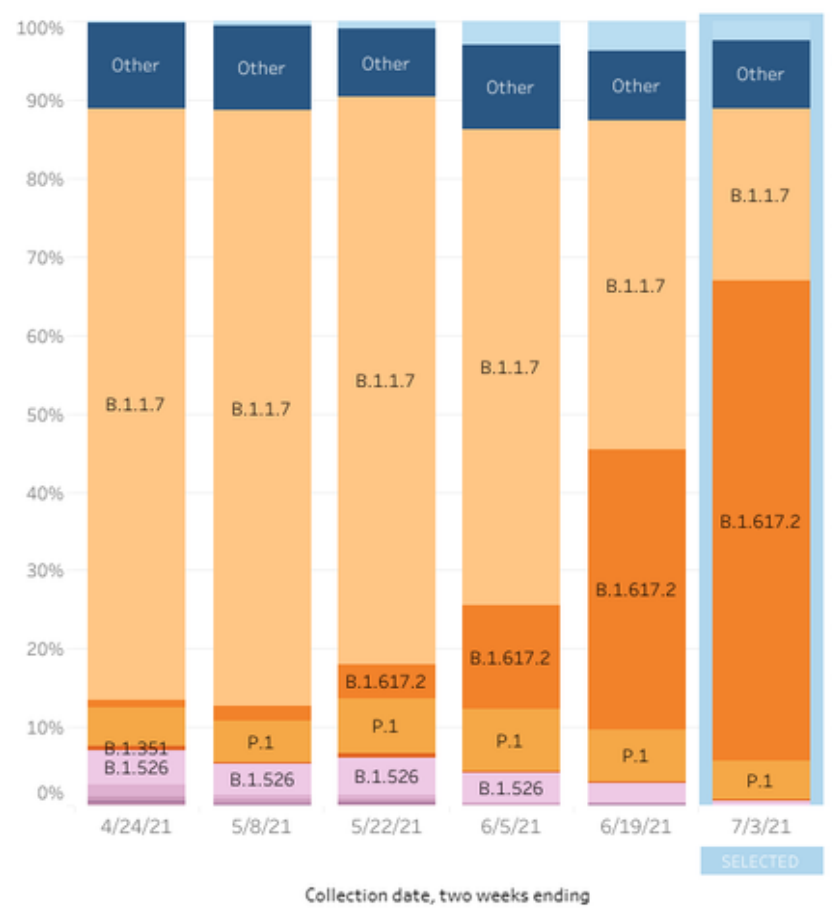

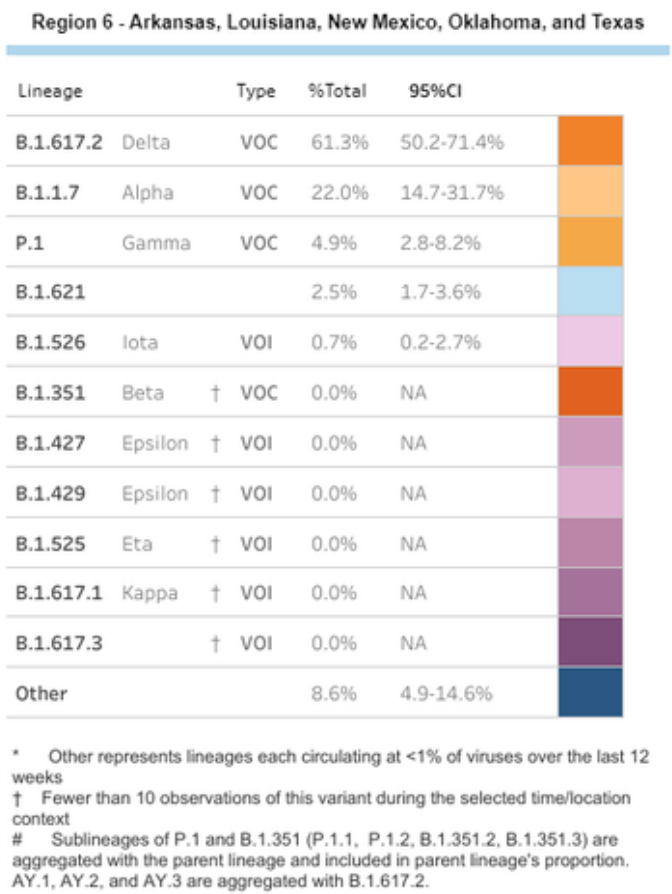

Estimated Proportions of SARS-CoV-2 Lineages for Health and Human Services Region 6, which includes Texas. Source: Centers for Disease Control and Prevention, https://covid.cdc.gov/covid-data-tracker/. Accessed 23 July 2021.

An increase in COVID-19 cases also creates more opportunities for the virus to mutate, which could lead to the emergence of new variants. Variants of the virus that causes COVID-19 are now responsible for all cases in the United States. The original strain is no longer detected among variants circulating throughout the country. The B.1.617.2 (Delta) variant is now the predominant variant in the United States, making up an estimated $\underline{83.2 \%}$ of recent U.S. cases. The best way to slow the emergence of new variants is to reduce the spread of infection by taking measures to protect yourself, including getting a vaccine when it's available to you.

COVID-19 is now a preventable disease. The COVID-19 vaccines authorized for use in the United States are safe and are effective against B.1.617.2 and other variants. If you receive a Pfizer-BioNTech or Moderna COVID-19 vaccine, you will need 2 shots to get the most protection. You should get your second shot even if you have side effects after the first shot, unless a vaccination provider or your doctor tells you not to get it. If you are only partially vaccinated, you are more likely to get infected, get sick, and spread the virus to other people. When you 
are fully vaccinated, you are protected against severe illness, hospitalization, and death.

Note to readers: To find a vaccine provider near you, visit Vaccines.gov or your state or local public health department website. You can also text your zip code to 438829 to get 3 locations near you with vaccines in stock. If you prefer your information in Spanish, text your zip code to 822862. You can also call the National COVID-19 Vaccination Assistance Hotline at 1-800-232-0233 to get help in English, Spanish, and more than 150 other languages. It also has a TTY line to support access by hearing impaired callers. If you or someone you know is hesitant about COVID-19 vaccination, CDC has information and answers to frequently asked questions to help inform the decision. $\underline{84}$

July 29, 2021: Texas Gov. Greg Abbott issues Executive Order 38 banning governmental entities from mandating COVID-19 vaccination or proof of vaccination to receive benefits or services ("vaccine passports") and overriding any locally issued COVID-19-related restrictions, including operating restrictions on businesses and requirements to wear masks. (Note schools cannot require masks to be worn but jails can.) He also removes the ability of local governments to jail those who violate public health orders. $\underline{85}$

July 30, 2021: $900^{\text {th }}$ COVID-19 death in Austin-Travis County. $\frac{86}{6}$

\section{August 2021}

August 2, 2021: State of Texas denies requests from hospitals for additional staffing as COVID-19 hospitalizations surge across the state. $\underline{87}$

August 4, 2021: Analysis shows Texas Republican leaders received significantly larger campaign donations from energy companies after the legislative session in what "looks like a reward for not passing more stringent regulations and raises questions about whether lawmakers let the oil, gas and the broader energy industry off easy for its massive failures." $\underline{88}$

August 9, 2021: Republican-controlled Texas Supreme Court declines to overturn Gov. Greg Abbott's veto that wiped out funding for the Legislature for the next two years. $\underline{89}$

August 10, 2021: Austin and surrounding area down to two intensive care unit (ICU) beds. Texas reaches lowest number of available ICU beds during the state has had 
entire pandemic. "Region $\mathrm{O}$ - which is made up of 2.3 million people in 11 counties: Travis, Williamson, Hays, Bastrop, Blanco, Burnet, Caldwell, Fayette, Lee, Llano and San Saba - had only two staffed ICU beds. . . . According to data, among the total hospitalized patients more than $80 \%$ are not vaccinated. Fully and partially vaccinated residents have been hospitalized but at $15.5 \%$ and $3.7 \%$ respectively." School districts and cities actively defy Gov. Abbott's orders by requiring masks be worn in schools and public buildings. $\frac{90}{}$ State District Judge Antonia “Toni” Arteaga issues a temporary restraining order blocking Gov. Abbott's order, clearing the way for the San Antonio Metropolitan Health District to require students and employees in public and private schools to wear masks and to quarantines in cases where unvaccinated students were exposed to people found to have COVID-19. $\underline{91}$ Judge Tonya Parker rules that Gov. Greg Abbott's executive order on mask mandates is "not [a] necessary action to combat the pandemic", and agreed to a temporary restraining order that will allow Dallas County Judge Clay Jenkins to require face coverings. $\underline{92}$

August 11, 2021: Gov. Greg Abbott and Attorney General Ken Paxton file their first court action to strike down mask mandates enacted by local officials in defiance of Abbott's ban on them. $\underline{93}$

August 19, 2021: Texas Lt. Gov. Dan Patrick falsely blames the most recent resurgence of COVID-19 patients on Black Americans.

Democrats like to blame Republicans on (low vaccination rates). Well, the biggest group in most states are African Americans who have not been vaccinated. The last time I checked, over $90 \%$ of them vote for Democrats.

- Texas Lt. Gov. Dan Patrick $\underline{94}$

August 25, 2021: Texas Gov. Greg Abbott issues executive order barring vaccination mandates and proof of vaccination to access services (vaccine passports"), adding the latter to his second special session call. $\underline{95}$ 


\section{COVID-19 drove a spike in Texas deaths}

Weekly fatalities, Jan. 1964 - Mar. 2021

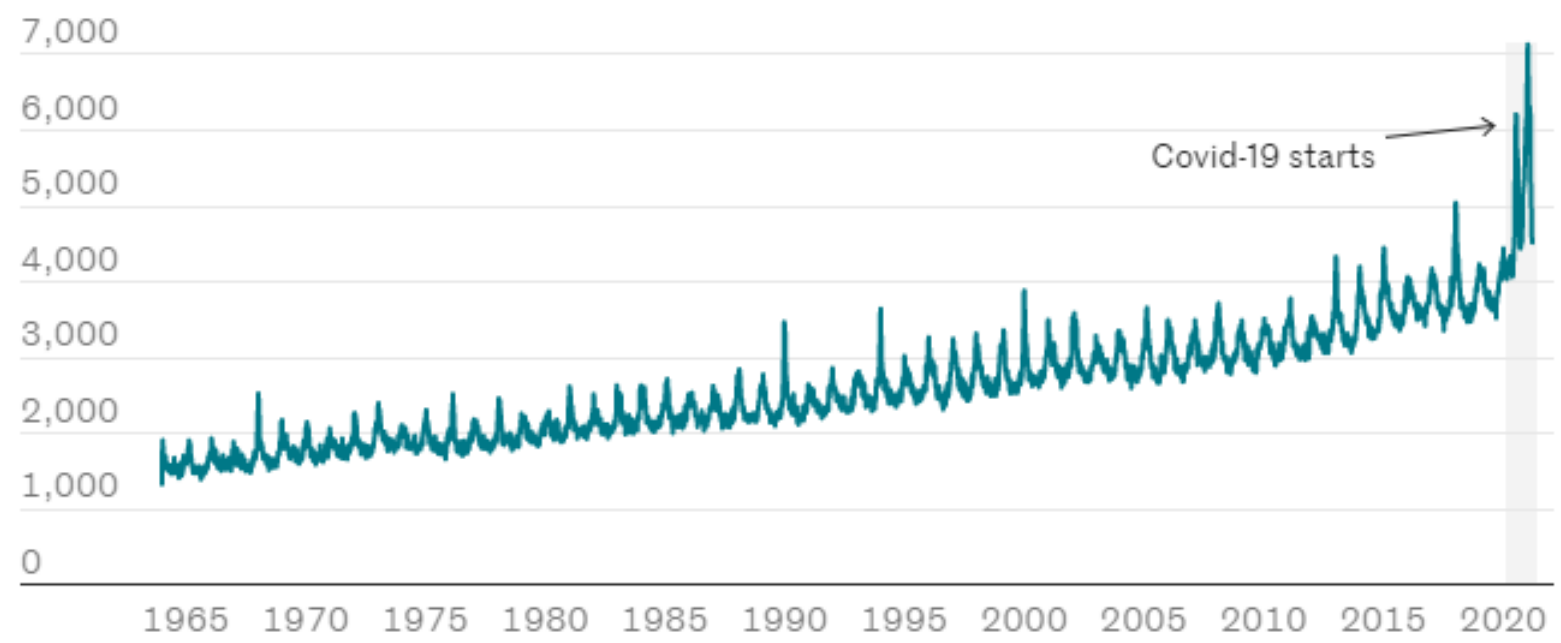

Chart: Zach Despart · Source: Texas DSHS

Despart, Zach. “New Chart Reveals Sobering Look at COVID's Impact on Texas Deaths." Houston Chronicle, 28 June 2021, https://www.houstonchronicle.com/news/houston-texas/health/article/The-impactof-COVID-19-on-Texas-deaths-in-one-16275226.php.

\section{6,345 - Total Texas deaths from COVID-19 as of 7:22 AM CT on August 28, 2021. .96}

Additional Resources:

- ERCOT's Preliminary Report on Causes of Generator Outages and Derates For Operating_Days February_14 - 19,2021 Extreme Cold Weather Event

- CIRCLE's State-by-State 2020 Youth Voter Turnout: The South

- Texas Department of State Health Services Winter Storm Deaths Tally.

- BuzzFeed News data analysis on Winter Storm Uri deaths in Texas

- Report from former Public Utility Commission of Texas members: Never Again: How to prevent another major Texas electricity failure

- Ratcliffe, R. G. "Texas Lawmakers Had Two Crises to Address. They Ignored Them in Favor of Sideshows." Texas Monthly, Texas Monthly, 1 June 2021. 
- Houston Chronicle's "Failures of Power" series documenting how 20 million Texans lost power in a deadly freeze after state lawmakers brushed aside a decade of warnings about the increasingly vulnerable electric grid.

- "Profit instead of safety,". May 20, 2021

- "I lost my best friend,"-May 24, 2021

- "Fixing Texas' unreliable power grid won't be cheap or easy. Can we trust politicians to get it done?", May 25, 2021

- "10 ways to fix the Texas power grid, according to experts," May 25, 2021

- City of San Antonio Community Emergency Preparedness Committee Report: A Response to the February 2021 Winter Storm

CEP\%20Report\%20Final[1] $]$.pdf $\quad 3$ MB

- City of Austin Winter Storm Review Task Force Final Report,July 30, 2021

- Texas Tribune's Coronavirus in Texas

- "Timeline of Irresponsibility" bibliography also available at https://zbib.org/ee4783e64c654d0db29d307d3661d37a.

William O. Pate II is the founding editor and publisher of San Antonio Review. He lives in Austin.

\section{Footnotes}

1.

World Health Organization. Novel Coronavirus (2019-NCoV): Situation Report, 3. Jan. 2020. appps.who.int, https://apps.who.int/iris/handle/10665/330762.

$\underline{-}$

2. "Fort Bend County Confirms First 'Presumptive' Case of COVID-19." KXAN Austin, 5 Mar. 2020, https://www.kxan.com/news/coronavirus/fort-bend-county= confirms-first-presumptive-case-of-covid-19/. 
3. Archived: WHO Timeline - COVID-19. https://www.who.int/news/item/27-04-2020who-timeline---covid-19. Accessed 30 June 2021.

4. "Fort Bend County Confirms First 'Presumptive' Case of COVID-19." KXAN Austin, 5 Mar. 2020, https://www.kxan.com/news/coronavirus/fort-bend-countyconfirms-first-presumptive-case-of-covid-19/. $\bullet$

5. "TIMELINE: How Coronavirus in Texas Unfolded since First Case One Year Ago." KXAN Austin, 4 Mar. 2021, https://www.kxan.com/news/coronavirus/365-daysof-covid-how-the-coronavirus-in-texas-unfolded-one-year-after-the-first-case/.. 6.

"TIMELINE: How Coronavirus in Texas Unfolded since First Case One Year Ago." KXAN Austin, 4 Mar. 2021, https://www.kxan.com/news/coronavirus/365-daysof-covid-how-the-coronavirus-in-texas-unfolded-one-year-after-the-first-case/.

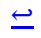

7. YouTube, FOX News, 2020, https://youtu.be/a9k-GeCtK9o. Knodel, Jamie. “Texas Lt. Gov. Dan Patrick Suggests He, Other Seniors Willing to Die to Get Economy Going Again.” NBCNews.com, NBCUniversal News Group, 24 Mar. 2020, www.nbcnews.com/news/us-news/texas-lt-gov-dan-patrick-suggests-he-otherseniors-willing-n1167341. “Tucker Carlson Tonight: March 23, 2020: Lt Gov Dan Patrick." YouTube, FOX News, 23 Mar. 2020, youtu.be/a9k-GeCtK9o.

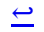

8. Ken, Paxton. TXAG Ken Paxton Letter to Rep. Klick. 14 Apr. 2020, https://www.texasattorneygeneral.gov/sites/default/files/images/admin/2020/Press/4.1 4.20\%20Letter\%20to\%20Rep.\%20Klick.pdf. “Texas AG Ken Paxton Was Indicted for Fraud 5 Years Ago. Will He Ever Face a Jury?” Dallas News, 27 July 2020, https://www.dallasnews.com/news/politics/2020/07/27/texas-ag-ken-paxton-wasindicted-for-fraud-5-years-ago-will-he-ever-face-a-jury $1 . \pm$ 9. Tiaji Salaam-Blyther, et al. U.S. Withdrawal from the World Health Organization: Process and Implications. CRS Report, R46575, Congressional Research Service, 21 Oct. 2020, https://crsreports.congress.gov/product/pdf/R/R46575. Accessed August $3,2021$. 
10. Sulak, Tim. TEXAS DEMOCRATIC PARTY, et. al v. DANA DEBEAUVOIR . No. D-1GN-20-001610, https://static.texastribune.org/media/files/d64f4a7d21b10c5fcf6246357168f9e5/Order \%20on\%20Application\%20for\%20Temporary\%20Injunctions\%20and\%20Plea\%20to\% 20the\%20Jurisdiction.pdf? ga =2.212722512.59683942.1616160891159978093.1596033717. Accessed August 3, 2021. 11. Abbott, Greg. Executive Order No. GA-17 Relating to the Establishment of the Governor's Strike Force to Open Texas. Office of the Governor of the State of Texas, 17 Apr. 2020, https://gov.texas.gov/uploads/files/press/EO-GA-

17 Open Texas Strike Force COVID-19 IMAGE_04-17-2020.pdf. Accessed August 3, 2021.

12. 'Trump Suggests 'injection' of Disinfectant to Beat Coronavirus and 'Clean' the Lungs." NBC News, https://www.nbcnews.com/politics/donald-trump/trump-suggestsinjection-disinfectant-beat-coronavirus-clean-lungs-n1191216. Accessed 5 Apr. 2021.

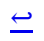

13. Plohetski, Tony. "Man Killed in Police Shooting Last Month Did Not Have Firearm, Chief Confirms." Austin American-Statesman, https://www.statesman.com/news/20200511/man-killed-in-police-shooting-last-monthdid-not-have-firearm-chief-confirms. Accessed 9 June 2021. 14.

Governor's Strike Force to Open Texas. The Governor's Report to Open Texas: Texans Helping Texans. Office of the Texas Governor, 27 Apr. 2020, https://open.texas.gov/uploads/files/organization/opentexas/OpenTexas-Report.pdf.

$\underline{\underline{ }}$

15. Error

"TIMELINE: How Coronavirus in Texas Unfolded since First Case One Year Ago." KXAN Austin, 4 Mar. 2021, https://www.kxan.com/news/coronavirus/365-daysof-covid-how-the-coronavirus-in-texas-unfolded-one-year-after-the-first-case/.

$\underline{-}$

16. Paxton, Ken. Texas AG Ken Paxton Letter to County Judges and County Election Official Re: Ballot by Mail Based on Disability. 1 May 2020, 
https://www.texasattorneygeneral.gov/sites/default/files/images/admin/2020/Press/Ma il-in\%20Ballot\%20Guidance\%20Letter 05012020.pdf..

17. Leaked Audio (Full): Gov. Abbott Knows Reopening Will Cause an Increase in Infection Rate for Texans. www.youtube.com, https://www.youtube.com/watch? v=Ck0C1e2Cahw. Accessed 19 Mar. 2021.

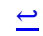

18. Ibid. $ヒ$

19. “U.S. District Judge Rejects Election Integrity Claims in Vote-by-Mail Case.” San Antonio Report, 20 May 2020, https://sanantonioreport.org/read-u-s-district-judgefred-bierys-vote-by-mail-decision/. $\triangleq$

20. "How George Floyd Died, and What Happened Next." The New York Times, 25 May 2021. NYTimes.com, https://www.nytimes.com/article/george-floyd.html. 21. Texas Supreme Court, IN RE STATE OF TEXAS (2020), https://www.txcourts.gov/supreme/orders-opinions/2020/may/may_27-2020/ 22. Doha Madani, et al. "Ex-Officer Who Knelt on George Floyd's Neck Charged with Murder.” NBC News, NBC News, 29 May 2020, https://www.nbcnews.com/news/usnews/minneapolis-police-officers-derek-chauvin-arrested-george-floyd-casen1216011. Accessed 3 August 2021. $\uplus$ 23. Tiaji Salaam-Blyther, et al. U.S. Withdrawal from the World Health Organization: Process and Implications. CRS Report, R46575, Congressional Research Service, 21 Oct. 2020, https://crsreports.congress.gov/product/pdf/R/R46575. Accessed August 3, 2021.

24. Gaspar, Jr., Eddie, Shelby Tauber, Pu Ying Huang and Miguel Gutierrez. “A Weekend of Protest and Mourning: George Floyd's Death Spurs Demonstrations in Texas Cities." The Texas Tribune, 30 May 2020, https://www.texastribune.org/2020/05/29/george-floyd-texas-protest-photos-houstondallas-austin/.

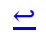

25. Samuels, Alex. "Texas Gov. Greg Abbott Declares State of Disaster after George Floyd Protests." The Texas Tribune, 31 May 2020, https://www.texastribune.org/2020/05/31/texas-greg-abbott-state-disaster-georgefloyd $l .$. 
26.

"TIMELINE: How Coronavirus in Texas Unfolded since First Case One Year Ago." KXAN Austin, 4 Mar. 2021, https://www.kxan.com/news/coronavirus/365-daysof-covid-how-the-coronavirus-in-texas-unfolded-one-year-after-the-first-case/.

$\underline{\underline{ }}$

27.

Abbott, Greg. Executive Order, GA-29. Relating to the use of face coverings during the COVID-19 disaster (coronavirus/masks), July 2, 2020. Legislative Reference Library, https://lrl.texas.gov/scanned/govdocs/Greg\%20Abbott/2020/GA-29.pdf. Accessed April 1, 2021.

Find all Gov. Abbott's executive orders at the Legislative Reference Library of Texas at https://lrl.texas.gov/legeLeaders/governors/displayDocs.cfm? govdoctypeID $=5 \&$ governorID $=45$. Accessed April 1, 2021. 28. "TIMELINE: How Coronavirus in Texas Unfolded since First Case One Year Ago." KXAN Austin, 4 Mar. 2021, https://www.kxan.com/news/coronavirus/365-daysof-covid-how-the-coronavirus-in-texas-unfolded-one-year-after-the-first-case/.. 29. "Strike Force to Open Texas Disbanded Months Ago." KTSM 9 News, 4 Mar. 2021, https://www.ktsm.com/news/texas-politics/strike-force-to-open-texas-disbandedmonths-ago/. "Abbott Quietly Disbanded His Strike Force to Open Texas. Five Months Later, He Lifted Pandemic Restrictions." Austin American-Statesman, https://www.statesman.com/story/news/2021/03/14/did-gov-greg-abbott-listen-hisstrike-force-open-texas/6924547002/. Accessed 29 Mar. 2021. 30. Abbott, Greg. Executive Order, GA 30. Relating to the continued response to the COVID-19 disaster as Texas reopens, September 17, 2020. Legislative Reference Library, https://lrl.texas.gov/scanned/govdocs/Greg\%20Abbott/2020/GA-30.pdf. Accessed April 1, 2021. 31. 
"TIMELINE: How Coronavirus in Texas Unfolded since First Case One Year Ago." KXAN Austin, 4 Mar. 2021, https://www.kxan.com/news/coronavirus/365-daysof-covid-how-the-coronavirus-in-texas-unfolded-one-year-after-the-first-case/.

$\Xi$

32. Wallace, Jeremy. "Texas Voter Turnout Was Best in Almost 30 Years." Houston Chronicle, 6 Nov. 2020, https://www.houstonchronicle.com/news/election2020/article/Texas-voter-turnoutwas-best-in-almost-30-years-15705990.php.. 33.

“Texas Becomes 1st State to Surpass 1 Million COVID-19 Cases." $A B C 27,11$ Nov. 2020, https://www.abc27.com/news/health/texas-becomes-1st-state-to-surpass-1million-covid-19-cases/.

$\uplus$

34. "Who Paid for Texas AG Ken Paxton to Travel to DC for the Jan. 6 Rally? We Asked. He Won't Answer.” Dallas News, 16 Feb. 2021, https://www.dallasnews.com/news/investigations/2021/02/16/texas-attorney_generalken-paxton-went-to-jan-6-rally-in-dc-but-he-wont-say-who-paid-for-his-trip $\perp . \subseteq$ 35. “Biden's US Revives Support for WHO, Reversing Trump Retreat." AP NEWS, https://apnews.com/article/us-who-support-006ed181e016afa55d4cea30af236227. Accessed 5 Aug. 2021.

36.

Chant, Tim De. "Texas Gov Knew of Natural Gas Shortages Days before Blackout, Blamed Wind Anyway.” Ars Technica, 21 May 2021, https://arstechnica.com/techpolicy/2021/05/texas-gov-knew-of-natural-gas-shortages-days-before-blackout-blamedwind-anywayl.

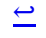

37. Sechler, Bob. "Lt. Gov. Dan Patrick Says Upcoming Bill Would Defend Texas Energy Sector from Boycotts." Statesman.com, Austin American-Statesman, 11 Feb. 2021, www.statesman.com/story/business/2021/02/11/lt-gov-calls-bill-defend-energy= 
sector-boycotts-priority/6726508002/. Spencer, Christian. “Texas Lawmakers Move to Raise Penalties on Owners of Teslas and Other Electric Vehicles." TheHill, 14 May 2021, https://thehill.com/changing-america/sustainability/energy/553661-texaslawmakers-move-to-raise-penalties-on-owners-of. $\doteq$

38. "Texas Winter Storm Death Toll Rises to 11 in Austin Area, 111

Statewide." Austin American-Statesman, https://www.statesman.com/story/news/2021/03/25/texas-winter-storm-death-tollaustin-travis-county/7003976002/. Accessed 29 Mar. 2021. See the current Texas Department of State Health Services tally at https://dshs.texas.gov/news/updates.shtm\#wn. Last accessed August 5, 2021. 39. Serrano, Zach Despart, Alejandro, and Stephanie Lamm. "Exclusive: Nearly 200 Died in Texas Cold Storm, Almost Double the Official Count." Houston Chronicle, 1 Apr. 2021, https://www.houstonchronicle.com/news/houstontexas/houston/article/texas-cold-storm-200-died-analysis-winter-freeze-16070470.php. $\underline{-}$

40.

"The Texas Winter Storm And Power Outages Killed Hundreds More People Than The State Says." BuzzFeed News, https://www.buzzfeednews.com/article/peteraldhous/texas-winter-storm-poweroutage-death-toll. Accessed 28 May 2021.

$\Xi$

41. PUBLIC UTILITY COMMISSION OF TEXAS. SECOND ORDER DIRECTING ERCOT TO TAKE ACTION AND GRANTING EXCEPTION TO COMMISSION RULES. PUBLIC UTILITY COMMISSION OF TEXAS, 16 Feb. 2021. PUC Docket No. 51617, Public Utility Commission of Texas, http://www.puc.texas.gov/51617WinterERCOTOrder.pdf. Accessed 15 June 2021. 42. Bryce, Robert. “Texas Ratepayers Are Being Saddled With Nearly \$38 Billion In Excess Energy Costs From Winter Storm Uri." Forbes, https://www.forbes.com/sites/robertbryce/2021/06/11/texas-ratepayers-are-being= saddled-with-nearly-38-billion-in-excess-energy-costs-from-winter-storm-uri/.

Accessed 15 June 2021. $ヒ$

43. “Fact-Check: Did Renewable Energy 'thrust' Texas into Widespread Power Outages?" Austin American-Statesman, https://www.statesman.com/story/news/politics/politifact/2021/02/19/texas-power- 
outage-energy_grid-wind-renewable-energy_greg-abbott-fact-check/4500251001/. Accessed 7 Apr. 2021.

44. Parker, Ashley. “One Night in Cancun: Ted Cruz's Disastrous Decision to Go on Vacation during Texas Storm Crisis." Washington Post. www.washingtonpost.com, https://www.washingtonpost.com/politics/ted-cruz-cancunstorm/2021/02/19/ce1dc25e-7252-11eb-93be-c10813e358a2 story.html. Accessed 29 Mar. 2021.

45. “Texas Attorney General Ken Paxton Traveled to Utah during Last Week's Power Outages." Dallas News, 22 Feb. 2021, https://www.dallasnews.com/news/investigations/2021/02/22/texas-attorney_generalken-paxton-traveled-to-utah-during-last-weeks-power-outages/.. 46. Goodman, Claire. "Fort Bend's Gary Gates Facing Backlash after Taking Jet to Florida amid Outages." Houston Chronicle, 19 Feb. 2021, https://www.houstonchronicle.com/neighborhood/sugarland/news/article/State-RepGary-Gates-facing-backlash-after-15963326.php.. 47. Perry, Rick. "What's Up in Texas?” House Republican Leader, 17 Feb. 2021, https://www.republicanleader.gov/whats-up-in-texas/.. 48. Root, Jay. “Exclusive: All-Night ERCOT Meeting Raises Questions about Abbott's Role in Power Pricing Debacle.” Houston Chronicle, 23 Apr. 2021, https://www.houstonchronicle.com/politics/texas/article/All-night-ERCOT-meetingraises-questions-about-16124189.php.

49. CNN, Christina Maxouris. "Here's How a Week of Frigid Weather and Catastrophe Unfolded in Texas." CNN, https://www.cnn.com/2021/02/21/weather/texas-winter-storm-timeline/index.html. Accessed 31 Mar. 2021. 50. CNN, Christina Maxouris. "Here's How a Week of Frigid Weather and Catastrophe Unfolded in Texas." $C N N$, https://www.cnn.com/2021/02/21/weather/texas-winter-storm-timeline/index.html. Accessed 31 Mar. 2021. 51. “Texas Attorney General Ken Paxton Traveled to Utah during Last Week's Power Outages." Dallas News, 22 Feb. 2021, 
https://www.dallasnews.com/news/investigations/2021/02/22/texas-attorney_generalken-paxton-traveled-to-utah-during-last-weeks-power-outages/. $\doteq$ 52.

Governor Abbott Lifts Mask Mandate, Opens Texas 100 Percent. https://gov.texas.gov/news/post/governor-abbott-lifts-mask-mandate-opens-texas-100percent. Accessed 27 Mar. 2021. Abbott, Greg. Executive Order, GA-34. Relating to the opening of Texas in response to the COVID-19 disaster, March 2, 2021. Legislative Reference Library of Texas, https://lrl.texas.gov/scanned/govdocs/Greg\%20Abbott/2021/GA-34.pdf. Accessed April 1, 2021.

$\underline{-}$

53. Tomlinson, Chris. "Leaked Recording Reveals Texas Will Not Overhaul Electricity Grid after Deaths." Houston Chronicle, 19 Mar. 2021, https://www.houstonchronicle.com/business/columnists/tomlinson/article/Texasgovernment-making-no-real-changes-to-16037054.php..

54. "Some on Wall Street Profited off Texas Blackouts. In a Private Call, a Top Regulator Pledged He Would Try to Protect Their Windfall." Texas Monthly, 16 Mar. 2021, https://www.texasmonthly.com/news-politics/wall-street-profited-off-texasblackouts/.

55. "AG Paxton Issues Letter to Austin Mayor and Travis County Judge Warning Against Unlawful Mask Orders." Texas Attorney General, https://www.texasattorneygeneral.gov/news/releases/ag-paxton-issues-letter-austinmayor-and-travis-county-judge-warning-against-unlawful-mask-orders. Accessed 27 Mar. 2021. $\doteq$

56. “Following Threat, AG Ken Paxton Sues Austin to End Mask Mandate." Austin American-Statesman, https://www.statesman.com/story/news/2021/03/11/ken-paxtonaustin-mask-mandate-texas-attorney-general/4652883001/. Accessed 27 Mar. 2021. 57. “Delay Lets Austin, Travis County Enforce Mask Mandates for Now.” Austin American-Statesman, https://www.statesman.com/story/news/2021/03/12/austinmask-mandate-travis-county-judge-lora-livingston-texas-ken-paxton/4663189001/. Accessed 27 Mar. 2021. $\doteq$ 
58. "Ken Paxton Refuses to Release Emails, Texts Sent at Trump Rally That Devolved into U.S. Capitol Riot." Austin American-Statesman, https://www.statesman.com/story/news/2021/03/25/texas-ag-ken-paxton-refusesrelease-messages-emails-texts-trump-rally-capitol-riot/6989141002/. Accessed 29 Mar. 2021. 59. Sen. Ted Cruz Refuses Request to Wear a Mask. Hear Dr. Sanjay Gupta's Response - CNN Video. Www.cnn.com, https://www.cnn.com/videos/media/2021/03/25/ted-cruz-reporter-mask-vaccinationssanjay_gupta-newday-sot-vpx.cnn. Accessed 31 Mar. 2021. 60 .

“Judge Allows Austin Mask Mandate to Continue, Rejecting Texas AG Ken Paxton's Arguments." Austin American-Statesman, https://www.statesman.com/story/news/2021/03/26/austin-mask-mandate-continuestexas-ken-paxton-rejected/7011102002/. Accessed 27 Mar. 2021.

Watch the hearing here: https://www.youtube.com/watch?v=nYy7HQXaCFk 61. Higgins-Dunn, Noah. "Biden Says States Should Reinstate Mask Mandates and Wait to Reopen Businesses as Covid Cases Rise." CNBC, 29 Mar. 2021, https://www.cnbc.com/2021/03/29/biden-says-states-should-reinstate-mask-mandatesand-wait-to-reopen-businesses-as-covid-cases-rise-html. $\doteq$

62. “New GOP-Led Voting Restrictions Move Forward in Texas." AP NEWS, 1 Apr. 2021, https://apnews.com/article/legislature-bills-voting-rights-elections-greg-abbott18c254a6597e7a13ea45205cb35b3dd2.

63. Ura, Alexa. "Texas Senate Advances Bill Limiting How and When Voters Can Cast Ballots, Receive Mail-in Voting Applications." The Texas Tribune, 1 Apr. 2021, https://www.texastribune.org/2021/04/01/texas-voting-restrictions-legislature/. $ヒ$ 64. Gov. Abbott letter to U.S. Department of Labor, https://gov.texas.gov/uploads/files/press/O-WalshMartin202105171215.pdf, accessed May 19, 2021.

65. Governor Abbott Announces End to Federal Pandemic-Related Unemployment Benefits. https://gov.texas.gov/news/post/governor-abbott-announces-end-to-federalpandemic-related-unemployment-benefits. Accessed 19 May 2021. 
66. “Federal Reserve Board - Survey of Household Economics and Decisionmaking." Board of Governors of the Federal Reserve System, https://www.federalreserve.gov/consumerscommunities/shed.htm. Accessed 19 May 2021.

67. The Fed - Report on the Economic Well-Being of U.S. Households in 2018 - May 2019.

https://www.federalreserve.gov/consumerscommunities/sheddataviz/unexpectedexpe nses-table.html. Accessed 28 May 2021.

68. Abbott, Greg. “Executive Order 36 Prohibiting Government Entities From Mandating Masks." Office of the Governor of Texas, State of Texas, https://gov.texas.gov/news/post/governor-abbott-issues-executive-order-36prohibiting=government-entities-from-mandating-masks. Accessed 20 May 2021. 69. Ratcliffe, R. G. “Texas Lawmakers Had Two Crises to Address. They Ignored Them in Favor of Sideshows." Texas Monthly, Texas Monthly, 1 June 2021, https://www.texasmonthly.com/news-politics/texas-lege-session-roundup/. 70.

Nobles, Ryan, et al. "Senate Republicans Block January 6 Commission.” CNN, 28 May 2021, https://www.cnn.com/2021/05/28/politics/january-6-commission-votesenate/index.html. Jamie Gangel and Michael Warren. "McConnell Doubles down to Pressure Republicans, Asking for 'a Personal Favor' to Block January 6 Commission." CNN, https://www.cnn.com/2021/05/27/politics/mcconnell-personalfavor-block-january-6-commission/index.html. Accessed 28 May 2021.

$\underline{\underline{ }}$

71. Justin, Raga. “Texas Sen. John Cornyn Calls Climate Change Advocacy a 'Cult.'” Dallas News, Dallas Morning News, 4 June 2021, https://www.dallasnews.com/news/politics/2021/06/04/texas-sen-john-cornyn-callsclimate-change-advocacy-a-cult/. $\doteq$ 72. Morgan O'Hanlon, and Allie Morris. "From Backing the Blue to the 'StarSpangled Banner': Bills That Are Becoming Law in Texas." Dallas News, Dallas Morning News, 21 June 2021, https://www.dallasnews.com/news/2021/06/21/from- 
backing-the-blue-to-the-star-spangled-banner-bills-that-are-becoming-law-in-texas/. Accessed 22 June 2021.

73. Sanders, Austin. "Austin Police Funding Restored; Is It Too Much, or Not Enough?" The Austin Chronicle, The Austin Chronicle, 30 July 2021, https://www.austinchronicle.com/news/2021-07-30/austin-police-funding-restored-isit-too-much-or-not-enough/. Accessed 3 August 2021.

74. "Notably, the Texas attorney general conflated mail-in ballots with applications for mail-in ballots in his remarks to Bannon. Harris County did not attempt to mail actual ballots to registered voters-just applications to request them if the individual voter wanted one." Lemon, Jason. "Texas AG Says Trump Would've 'Lost' State If It Hadn't Blocked Mail-in Ballots Applications Being Sent Out." Newsweek, Newsweek Digital LLC, 5 June 2021, https://www.newsweek.com/texas-ag-says-trump-wouldvelost-state-if-it-hadnt-blocked-mail-ballots-applications-being-1597909. 75. Weber, Paul. "Texas Governor Says Power Grid Fixed; Experts Cite Problems.” AP NEWS, Associated Press, 8 June 2021, https://apnews.com/article/texas-business-government-and-politics33520b14d1823108a3c654d611701987. Accessed 9 July 2021.

76. Morgan O'Hanlon, and Allie Morris. "From Backing the Blue to the 'StarSpangled Banner': Bills That Are Becoming Law in Texas." Dallas News, Dallas Morning News, 21 June 2021, https://www.dallasnews.com/news/2021/06/21/frombacking-the-blue-to-the-star-spangled-banner-bills-that-are-becoming-law-in-texas/. Accessed 22 June 2021.

77. Ibid. $\_$

78. Ibid. $\_$

79. Pollock, Cassandra. "Gov. Greg Abbott Vetoes Funding for Texas Legislature and Its Staff as Punishment for Democrats' Walkout on Elections Bill." The Texas Tribune, 18 June 2021, https://www.texastribune.org/2021/06/18/greg-abbott-vetolegislature-democrats/. Accessed 22 June 2021. 80. Pollock, Cassandra. "Texas Gov. Greg Abbott Sets July 8 Date for Special Legislative Session on Voting Bill, Other Issues." The Texas Tribune, 22 June 2021, https://www.texastribune.org/2021/06/22/texas-greg-abbott-special-session/... 
81. Smith, Kelli. "Half of Texas' Eligible Population Fully Vaccinated as 419 New COVID-19 Cases, 11 Deaths Reported." Dallas News, The Dallas Morning News, 4 July 2021, https://www.dallasnews.com/news/public-health/2021/07/04/half-of-texaseligible-population-fully-vaccinated-as-419-new-covid-19-cases-11-deaths-reported/. Accessed 6 July 2021.

82. “Texas Legislature Moves Quickly on Contentious Election Bills as Special Session Opens." Dallas News, Dallas Morning News, 8 July 2021, https://www.dallasnews.com/news/politics/2021/07/08/texas-legislature-movesquickly-on-contentious-election-bills-as-special-session-opens/. $\bullet$ 83. “COVID-19 Risk-Based Guidelines | AustinTexas.Gov.” COVID-19 Risk-Based Guidelines / AustinTexas.Gov, Austin Public Health / City of Austin, http://www.austintexas.gov/page/covid-19-risk-based-guidelines. Accessed 23 July 2021.

84. CDC. “COVID Data Tracker Weekly Review." Centers for Disease Control and Prevention, Centers for Disease Control and Prevention, 23 July 2021, https://www.cdc.gov/coronavirus/2019-ncov/covid-data/covidview/index.html. Accessed 23 July 2021. 85. Abbott, Greg. Executive Order No. GA-38 Relating to the Continued Response to the COVID-19 Disaster. Office of the Governor of the State of Texas, 29 July 2021, https://gov.texas.gov/uploads/files/press/EO-GA-

38 continued response to the COVID-19 disaster_IMAGE_07-29-2021.pdf. Accessed 3 August 2021.

86. “Today in Austin: Austin-Travis County Marks the 900th Death Due to COVID19." Today in Austin, 30 July 2021, https://todayinaustin.blogspot.com/2021/07/austintravis-county-marks-900th-death.html. $\doteq$

87. 'Texas Officials Deny Hospitals' Requests for Hundreds of Emergency Staff to Help with COVID Surge.” wfaa.com, 5 Aug. 2021, https://www.wfaa.com/article/news/health/coronavirus/texas-officials-deny-hospitalsrequests-hundreds-emergency-staff-help-covid-surge/287-a93342ab-29b4-47ee-acf02a70718ff670.

88. Astudillo, Mitchell Ferman and Carla. “Energy Industry Showers Gov. Greg Abbott, Other Texas Politicians with Campaign Cash after They Passed Power Grid Bills." The Texas Tribune, 4 Aug. 2021, 
https://www.texastribune.org/2021/08/04/texas-energy-industry-donationslegislature/. Accessed August 5, 2021. 89. “Texas Supreme Court Declines to Overturn Gov. Greg Abbott’s Veto of Legislature's Budget." Austin American-Statesman, https://www.statesman.com/story/news/2021/08/09/texas-supreme-court-gov-greg= abbott-veto-legislature-budget-decline/5545792001/. Accessed 12 Aug. 2021. 90. Scherer, Jasper. "Big Texas Cities Are in Open Revolt over Abbott's Ban on Mask Requirements." Houston Chronicle, 11 Aug. 2021, https://www.houstonchronicle.com/news/houston-texas/houston/article/Urban-Texasbucks-Gov-Abbott-s-ban-on-school-16378373.php. Accessed 12 August 2021. 91. Zavala, Guillermo Contreras, Elizabeth, and Laura Garcia. "'I Don't Do This Lightly': Judge Allows San Antonio and Bexar County to Issue Mask Mandate." Houston Chronicle, 10 Aug. 2021, https://www.houstonchronicle.com/coronavirus/article/San-Antonio-Bexar-sue-AbbottCOVID-mask-16376946.php. Accessed August 12, 2021. 92. “Dallas Judge Rules That Abbott's Mask Mandate Ban Cannot Be Enforced, Paves Way for New Requirements.” Dallas News, 10 Aug. 2021, https://www.dallasnews.com/news/courts/2021/08/10/parents-of-12-dallas-county_ children-want-a-judge-to-overthrow-gov-abbotts-order-against-masks/. Accessed August 12, 2021.

93. Scherer, Jasper. "Gov. Abbott Moves to Strike down Mask Mandates Enacted by Defiant Local Officials." Houston Chronicle, 11 Aug. 2021, https://www.houstonchronicle.com/politics/texas/article/They-gave-the-governor-thepower-Texas-AG-16380798.php. Accessed August 12, 2021.

94. Mulder, Brandon. "Dan Patrick Said the Unvaccinated Black Community Is Driving the COVID Surge. We Fact-Checked Him." Austin American-Statesman, 27 Aug. 2021, https://www.statesman.com/story/news/politics/politifact/2021/08/27/nocovid-surge-cant-pinned-black-population/5601748001/. Accessed 28 August 2021. 95. Abbott, Greg. Executive Order No. GA-39 Relating to Prohibiting Vaccine Mandates and Vaccine Passports Subject to Legislative Action. Office of the Governor of Texas, 25 Aug. 2021, https://gov.texas.gov/uploads/files/press/EO-GA39 prohibiting_vaccine mandates and vaccine_passports IMAGE 08-25-2021.pdf. Texas Secretary of State. $\bullet$ 
96. “Texas - COVID-19 Overview - Johns Hopkins.” Johns Hopkins Coronavirus

Resource Center, https://coronavirus.jhu.edu/region/us/texas. Accessed 23 July 2021. $\underline{-}$ 